Health Service provision of condoms has so far been largely local and piecemeal. A few authorities have looked at using barrier methods in the prevention of AIDS, and the drug clinics and genitourinary departments of some London teaching hospitals have been distributing free condoms. Efforts will need to be centrally coordinated, and health authorities should be allowed to supply condoms and spermicides to those at risk. The Department of Health and Social Security must decide whether condoms should be provided free of charge for prophylaxis as they are in family planning clinics for contraceptive use. The question should surely no longer be whether to put the case for condoms in the fight against AIDS but rather how.

Kaye Wellings

Research Officer,

Family Planning Information Service,

London W1N 7RJ

1 Voeller $B$, Potts $M$. Has the condom any proved value in preventing the transmission of sexually transmitted viral disease-for example, acquired immune deficiency syndrome? $\mathrm{Br}$ Med $\mathcal{J}$ 1985 ;ii: 1196 .

2 Conant M, Hardy D, Sernatinger J, Spicer D, Levy JA. Condoms Prevent Transmission of AIDSAssociated Retrovirus. FAMA 1986;255:1706.

3 Hicks DR, Martin LS, Getchell JP, et al. Inactivation of HTLV III/LAV-infected cultures of normal human lymphocytes by nonoxynol 9 in vitro. Lancet 1985 ;ii:1422-3.

\section{AIDS, them, and us}

Most news about the acquired immune deficiency syndrome (AIDS) is depressing, but last week several events gave grounds for some cautious optimism that public perceptions of the disease are-at last-becoming more realistic. Firstly, the government set up a cabinet committee headed by Lord Whitelaw; its task will be the development and coordination of policies to contain the disease. ${ }^{12}$ Secondly, the voters in California-which is one of the two main focuses of the disease in the United States-decisively rejected proposition 64 , which would have made AIDS a notifiable disease and might have led to demands for quarantining carriers of the human immunodeficiency virus (HIV). ${ }^{3}$ Thirdly, the Manchester City Council announced that it would protect the jobs of any employees who contracted AIDS or were found to have antibodies to HIV. ${ }^{+5}$ Fourthly, for the first time advertisements warning about AIDS and giving explicit advice on how to avoid it were shown on British television. ${ }^{6}$

Why are these decisions grounds for optimism? Because they suggest that politicians and the public have begun to see AIDS as a threat to their own (and their families') health rather than as a disease restricted to homosexuals and drug addicts. Campaigning bodies such as the College of Health have been arguing this line for several years, ${ }^{7}$ but until recently the public has associated AIDS almost exclusively with homosexuals (in whom it was first described). Paradoxically, the link with homosexuality has been highlighted by the prime source of information for individuals and journalists having been the Terence Higgins Trust, which was set up by homosexuals in memory of one of the first homosexual victims of AIDS in Britain. ${ }^{8}$ It now seems that AIDS is linked with homosexuality only in the same way as are syphilis and hepatitis B: all three diseases are commonest in people who have very many sexual partners.

If AIDS is now being seen as a sexually transmitted disease that has features similar to those of syphilis and hepatitis B and may affect us all what conclusions follow? We need to remember that for the first half of this century syphilis was a potentially fatal disorder that affected unsuspecting consort and children as well as prostitutes (of both sexes) and their clients. Doctors now approaching retirement can recall the importance of excluding syphilis at an early stage in diagnosis of all patients, and the same is becoming true of AIDS Experience with syphilis also has important lessons for us in terms of the unproductiveness of punitive public healt measures-for example, compulsory blood tests and treat四 ment for prostitutes.

As explained in the previous leading article condom $\overrightarrow{\vec{F}}$ combined with spermicides seem to give protection agains transmission of the HIV virus. The prime task for Lor Whitelaw's committee must be spreading two simple messages to all sectors of society: the high risk activity fo $\mathbb{B}$ AIDS is sexual intercourse, and condoms give some protecon tion. The committee's remit will not, however, be confined to improving public health education. It will need, for example, to formulate policies on screening occupationad groups and visitors and immigrants to Britain; to advise building societies, banks, and insurance companies on the extent to which they can insist on their clients being tested fot carriage of HIV and the conditions that should be attached t\& loans made to those who have antibodies; to look at the financial burdens being carried by the few health districts which, at present, treat most of the patients with AIDS; and to identify research topics that Britain should tackle, bearing in mind the far greater resources in the United States.

The $B M \mathcal{F}$ has views on all these issues-as do many othe $\vec{G}$ organisations and individuals. On screening we have seen n尹 convincing arguments in favour of screening foreigner coming into Britain. Indeed, British citizens travelling abroad and returning are probably just as great a healtie hazard as immigrants and visitors-for many years sexuall transmitted diseases have been second only to diarrhoes among infections brought home by travellers abroad $ॄ$ Furthermore, to be effective and acceptable any controls of restraints on travellers would need to be worked out with the World Health Organisation, which tries to keep regulation\& to the minimum. And, of course, AIDS does not spread b. contagion or by mosquitoes. On research, we believe that Britain has unusual opportunities for studies in the com 3 munity on cohorts of people other than homosexuals who have become antibody positive-notably drug addicts and. patients with haemophilia. Careful follow up of these cohort will provide data for counselling and for forecasting future patterns of the epidemic.

All the projections point to continued growth in the numbers of patients with AIDS and of carriers of the viruso Slowly, however, facets of the epidemic are being identified that are not entirely black. The virus seems less infectiou $\$$ than the hepatitis B virus (at least in its effects on healtio workers who sustain needle stick injuries). Sheaths and spermicides do give useful protection. And sexual behaviour is being modified among both homosexuals and hetero요 sexuals. If, indeed, the task of combating AIDS is noww perceived as one facing the whole community we may have some hope.

Deputy editor, $B M \mathcal{F}$

TONY SMIT

1 Hughes C. Cabinet takes up the battle against AIDS. Independent 1986 Nov 3:pl (cols 1-3). 2 Prentice T. More cash for aids battle. The Times 1986 Nov 4:pl (cols 3-5).

3 Anonymous. Californians are taking the English course. Independent 1986 Nov 6:p8(col 6).

4 Anonymous. Council to protect workers with aids. Independent 1986 Oct 30:p3 (cols 5-6).

5 Morris M. Council to guarantee rights of workers with aids. The Times 1986 Oct 30:p2 $(\mathrm{col} 1)$.

6 Brown M. AIDS campaign launched on TV. Independent 1986 Nov 6:p3 (cols 5-6).

7 Anonymous. AIDS: act now, don't pay later (Editorial). Br Med f 1986;293:348.

8 Leach G, Whitehead A. AIDS and the gay community: the doctor's role in counselling. Br Med 1985;290:583. 